\title{
Pediatric abdominal chylolymphatic cysts-sneaky abdominal masqueraders
}

\author{
Ferzine Mohamed(D) \\ Department of Paediatric Surgery, Christian Medical College, Tamil Nadu, India
}

\begin{abstract}
Chylolymphatic mesenteric cyst of the abdomen is a rare differential for cystic tumors, more so in the pediatric age group and has varied clinical presentations. There have been very few cases reported worldwide. To the best of our knowledge, a multicystic chylolymphatic cyst of the abdomen as demonstrated below is the first reported occurrence worldwide in the paediatric age group.
\end{abstract}

Keywords: Mesenteric cyst, chylous cyst, atypical presentation, abdominal cysts

Cite this article as: Mohamed F. Pediatric abdominal chylolymphatic cysts-sneaky abdominal masqueraders Turk J Surg 2021; 37 (2): 179-182.

Corresponding Author

Ferzine Mohamed

E-mail: fuzzmohamed@gmail.com

Received: 07.02.2017

Accepted: 05.05.2017

Available Online Date: 30.06 .2021

๑ Copyright 2021 by Turkish Surgical Society Available online at www.turkjsurg.com

DOI: $10.47717 /$ turkjsurg.2021.3830

\section{INTRODUCTION}

Mesenteric cysts of the abdomen occur with exceedingly rare frequencies, more so in the paediatric population with an incidence of 1:100,000 in adults and 1:20,000 in children (1). They are most commonly found in the small bowel as compared to the large bowel, the ileum being the relatively more common site (2). Chylolymphatic cysts of the mesentery are chyle filled cysts characterized by the absence of smooth muscle and lymphatic spaces in the cyst wall $(1,3)$. The exact theory of origin of these cysts is not known but a variety of possible explanations have been proposed; the most widely accepted being Gross' theory of benign proliferation of ectopic mesenteric lymphatics which have been excommunicated from the main lymphatic channels (4). They commonly present as solitary cysts or multiloculated cysts. Multiple lymphatic cysts of the small bowel arranged in a chain tightly attached to a segment of small bowel is rare as described in the case below.

\section{CASE REPORT}

A 1-year-old male child presented to us with gradually progressing abdominal distension for the past 4-5 months with occasional episodes of vomiting which was non bilious. There was history of occasional constipation. On evaluation at his hometown, he was treated with ATT (anti tuberculous treatment) for a mistaken diagnosis of abdominal tuberculosis as his ultrasound revealed loculated ascites. After the medication, his mother did report some decrease in size. Clinical examination revealed a large mass of size $10 \times 12 \mathrm{~cm}$ which was lobulated, variegated in consistency (cystic in some areas, firm in others) and partly mobile (Figure 1).

Ultrasound imaging of the abdomen revealed a well-defined large, heterogenous, predominantly multicystic lesion- $9.4 \times 12.2 \mathrm{~cm}$ extending from epigastrium up to the urinary bladder with no significant interval vascularity.

On a computed tomogram (CT) (Figure 2), the same lesion was found to have multiple enhancing septae within the lesion with bowel loops enmeshed within. His blood investigations were within normal limits.

Intraoperatively, he was found to have multiple cysts of varying sizes and colors, some hemorrhagic, arranged in a chain along the mesentery of the duodenum commencing at $4 \mathrm{~cm}$ from the duodenojejunal flexure and extending up to 20 $\mathrm{cm}$. (Figure 3) An attempt was made to individually excise the cysts; however, that 


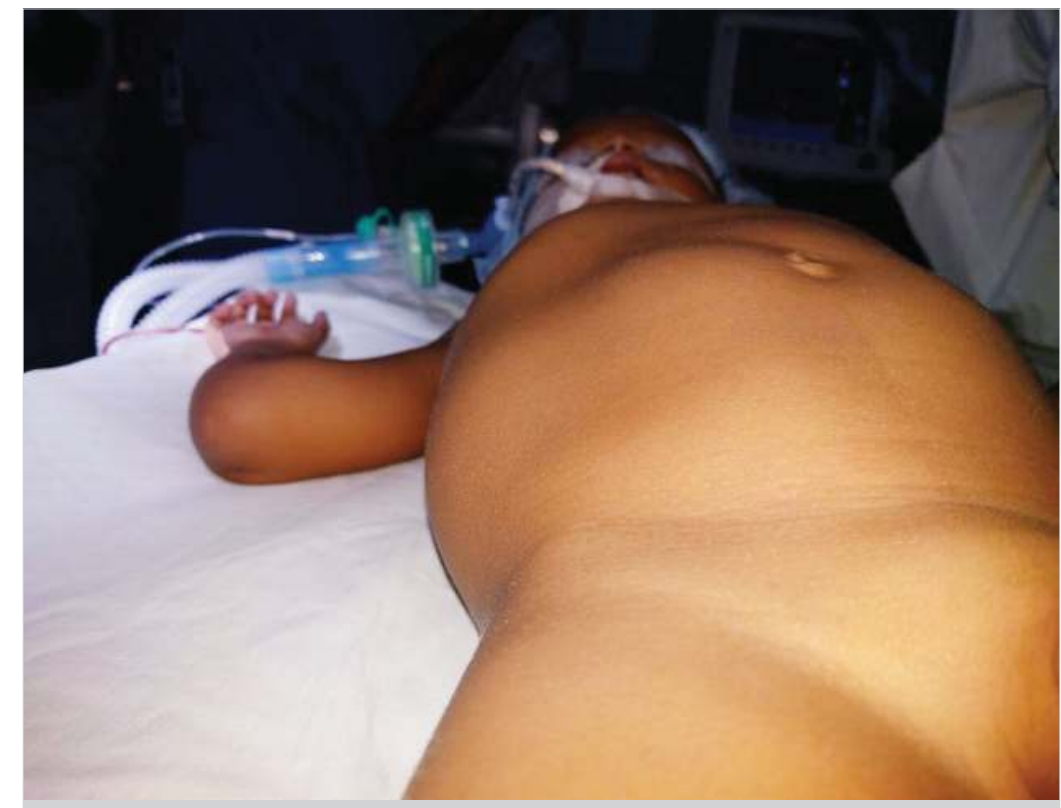

Figure 1. Pre-operative photograph-clinical presentation.

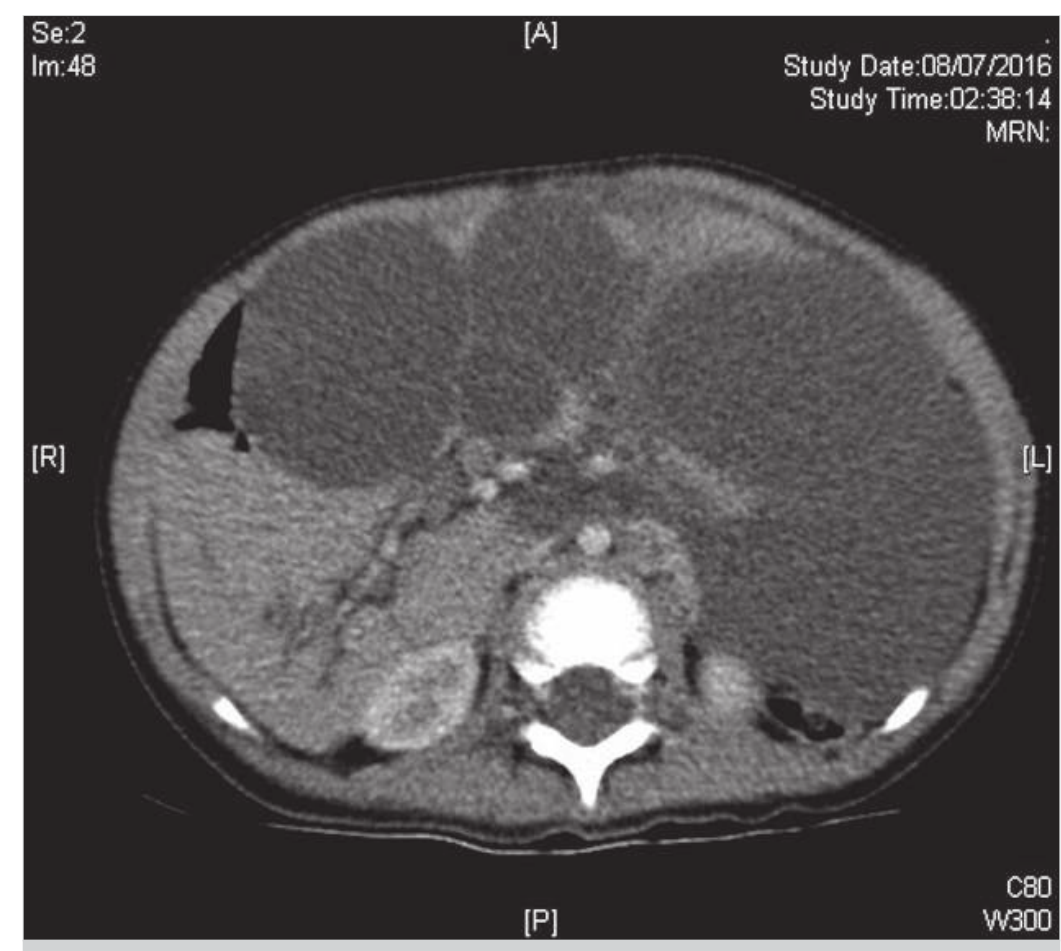

Figure 2. CT image of the loculated cysts

caused the rupture of the cysts leading to leakage of milky chylous fluid, and proceeding would have rendered the mesenteric vascular supply precariously compromised. A resection was hence performed on the affected segment with the multiple cysts and an end to end double layer bowel closure with closure of the mesenteric defect was performed after confirming a good vascular supply to the bowel. The entire specimen was sent in total for histopathological examination which revealed that the histopathology of the excised cyst showed the wall composed of a single layer of flattened cells with compressed connective tissue, consistent with the chylolymphatic cyst.

His postoperative period was uneventful.

\section{DISCUSSION}

Mesenteric cysts was first reported in the 16. century (2). They are rare with an incidence of 1:100,000 in adults and 1:20,000 in 


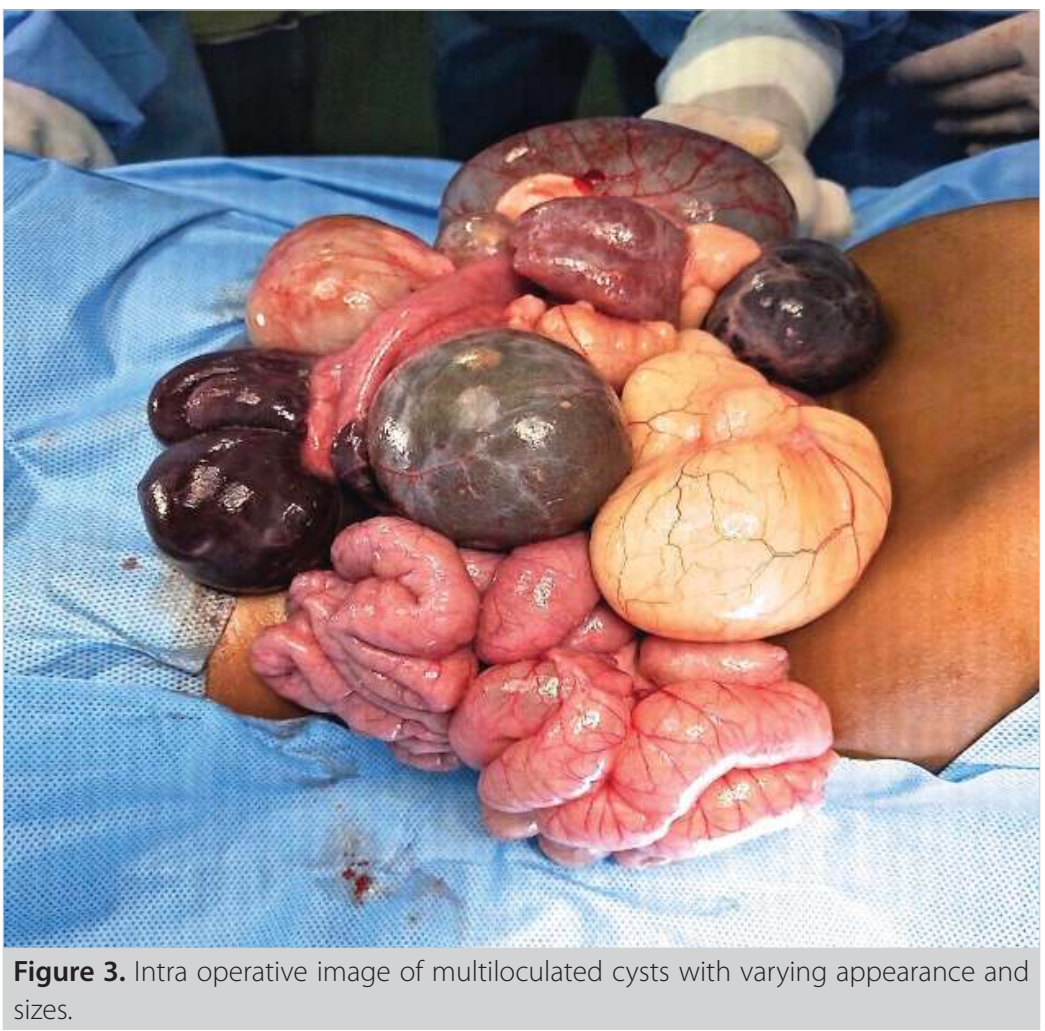

children (3). Chylolymphatic cysts comprise $7.3 \%$ of all mesenteric cysts and are characterized by the absence of smooth muscle and lymphatic spaces in the cyst wall (3-5). They are most commonly found in the small bowel as compared to the large bowel, the iteum being the relatively more common site (6). The exact theory of origin of these cysts is not known but a variety of possible explanations have been proposed; the most widely accepted being Gross' theory of benign proliferation of ectopic mesenteric lymphatics which have been excommunicated from main lymphatic channels (2). The usual occurrence is that of a solitary or multicystic lesion closely applied to the bowel wall, which to the best of our knowledge, has never been reported before. A similar case was described in an adult aged 35 years old published in 1992 (7)

Clinically, the patient may be asymptomatic or present with an abdominal mass, acute abdomen due to rupture, infection, hemorrhage into a cyst or volvulus or intestinal obstruction or other atypical presentations. Especially in endemic areas like ours, the presence of large chylolymphatic cysts can be mistaken for the more common loculated tuberculous ascites (8). Although tuberculosis would be a more common differential diagnosis to consider, emphasis has to be made that the diagnosis of these multiple chylolymphatic cysts; albeit rare; has to be kept in mind while dealing with patients who present with multiple cystic lesions in the abdomen. A Computed Tomogram is a useful adjunct in the evaluation of patients with abdominal distension.
Differential diagnoses considered in this case include mesenteric lymphangioma and MPIC (multilocular peritoneal inclusion cysts). These are distinct histologically; lack of smooth muscle and lymphatic spaces in the cyst wall seen in chylolymphatic cysts which will be demonstrated in a lymphangioma (3). An MPIC shows mesothelial cells on histopathology (4).

Current management guidelines recommend complete resection of the cyst either by enucleation or if blood supply to the bowel has to be sacrificed, resection and anastomosis of the closely applied bowel loop should be performed as in our case.

\section{CONCLUSION}

Chylolymphatic cysts should be borne in mind as one of the differential diagnoses of cystic masses in the abdomen in the pediatric age group. Multiple chylolymphatic cysts rarely occur, but their clustered appearance with a negative work up for tuberculosis should warrant further imaging and a reconsideration of management options. In an endemic country for Tuberculosis such as India, this differential should also be borne in mind. Adequate surgical treatment includes a complete excision with resection and anastomosis of the affected bowel.

\section{Take Home Messages}

1. Chylolymphatic cysts are a rare cause of abdominal distension in children. 
2. Computed Tomogram is a useful adjunct in the evaluation of abdominal distension of unknown etiology (especially if the diagnosis is questionable).

3. En bloc bowel resection with the cyst may be required.

Informed Consent: Informed consent has been obtained from the patient's guardian before submission of this article.

Peer-review: Externally peer-reviewed.

Author Contributions: Concept - F.M.; Design - F.M.; Supervision - F.M.; Materials - F.M.; Data Collection and/or Processing - F.M.; Analysis and/or Interpretation - F.M.; Literature Search - F.M.; Writing Manuscript - F.M.; Critical Reviews - F.M

Conflict of Interest: No conflict of interest was declared by the authors.

Financial Disclosure: The authors declared that this study has received no financial support.

\section{REFERENCES}

1. Javed A, Pal S, Chattopadhyay TK. Chylolymphatic cysts of the mesentery Trop Gastroenterol 2011;32(3):219-21. [CrossRef]
2. Ghritlaharey RK, More S. Chylolymphatic Cyst of mesentery of terminal ileum: a case report in 8-year-old boy. J Clin Diagn Res JCDR 2014; 8: ND05-ND07. [CrossRef]

3. Rattan KN, Nair VJ, Pathak M, Kumar S. Pediatric chylolymphatic mesenteric cyst - a separate entity from cystic lymphangioma: a case series J Med Case Reports 2009; 9(3): 111. [CrossRef]

4. Mohamed F. Pediatric abdominal chylolymphatic cysts-sneaky abdominal masqueraders. Turk J Surg 2018. [CrossRef]

5. Lee DLP, Madhuvrata P, Reed MW, Balasubramanian SP. Chylous mesenteric cyst: a diagnostic dilemma. Asian J Surg 2016; 39(3): 182-6. [CrossRef]

6. Hourani M, Mneimne M, Hourani A, Daoud N, Yassin N. Chylous mesenteric cyst with constipation: unusual presentation. Journal of Solid Tumors 2013; 3(3): 39-43. [CrossRef]

7. Kamat MM, Bahal NK, Prabhu SR, Pai MV. Multiple chylous cysts of abdomen causing intestinal obstruction. J Postgrad Med 1992; 38(4): 206. [CrossRef]

8. Lee DLP, Madhuvrata P, Reed MW, Balasubramanian SP. Chylous mesenteric cyst: a diagnostic dilemma. Asian J Surg 2016; 39(3): 182-6. [CrossRef]

\section{OLGU SUNUMU-ÖZET}

Turk J Surg 2021; 37 (2): 179-182

\section{Çocuk yaşta chylolenfatik mezenter kisti-sinsi abdominal taklitçiler}

Ferzine Mohamed

Christian Tıp Üniversitesi, Çocuk Cerrahi Anabilim Dalı, Tamil Nadu, Hindistan

\section{ÖZET}

Abdominal chylolenfatik mezenter kisti, kistik tümörlerin nadir karşılaşılan bir türü olmakla birlikte çocuk yaş grubunda neredeyse hiç karşılaşılmamaktadır ve çeşitli klinik prezentasyonları vardır. Dünya çapında çok az sayıda olgu bildirilmiștir. Bildiğimiz kadarıyla, bu olgu sunumunda bildirdiğimiz abdominal multikistik chylolenfatik kisti, çocuk yaş grubunda dünya çapında bildirilen ilk olgudur.

Anahtar Kelimeler: Mezenter kisti, şilöz kisti, atipik prezentasyon, abdominal kist

Doi: $10.47717 /$ turkjsurg.2021.3830 